\title{
Uma análise da extradição no Direito brasileiro
}

\author{
Fabiane Segabinazi ${ }^{\star}$
}

\section{INTRODUÇÃO}

O direito internacional visa a paz e a harmonia social na coletividade mundial e para bem desempenhar seu desiderato, utiliza-se de regras de convivência e de cooperação entre as diversas nações.

Quando um indivíduo nacional de um país comete um crime e evade-se para os domínios de outro a fim de esquivarse de responsabilidade judicial surge a necessidade de cooperação entre esses países envolvidos para recompor o equilíbrio social então quebrado, reconduzindo o indivíduo para que arque com sua responsabilidade judicial e social, onde e para quem de direito.
A esse pedido e consentimento de entrega do indivíduo chamamos extradição.

A palavra extradição tem origem no latim ex-traditione (ex: fora; traditione: entrega; entrega fora das fronteiras), significando traditio extra territorium. No passado, as palavras delito, remissio e intercum eram utilizadas para designar a entrega de criminosos.

Extradição é o instituto pelo qual "o governo de uma nação pede ao de outra que lhe entregue certo indivíduo que se homiziou no seu território por haver praticado um crime no país de onde saiu, a fim de que, perante a sua justiça, seja julgado ou cumpra a pena que lhe foi imposta".'

\footnotetext{
* Professora de Direito Civil e Processual Civil na Universidade da Região da CampanhaURCAMP, Alegrete e São Gabriel. Especialista em Direito Internacional Público, Privado e Direito da Integração pela Universidade Federal do Rio Grande do Sul - UFRGS. Especialista em Educação pela Universidade da Região da Campanha - URCAMP.

1 NUNES, Pedro. Dicionário de Tecnologia Jurídica. 12. ed. Rio de Janeiro: Freitas Bastos, $1994,954 \mathrm{p}$.
} 
Nos dizeres do insigne jurista Hildebrando Accioly ressaltando a subjetividade do instituto: "é o ato mediante o qual um Estado entrega a outro individuo acusado de haver cometido crime de certa gravidade ou que já se ache condenado por aquele, pós haver se certificado de que os direitos humanos do extraditando serão garantidos". 2

Está fundada no interesse recíproco das nações visando a punibilidade dos delitos, com base no princípio moderno do auxílio mútuo que deve existir entre os Estados. ${ }^{3}$

A Convenção sobre a Condição dos Estrangeiros assinada pelos Estados Americanos por ocasião da $6^{\mathrm{a}}$ Conferência Interamericana em Havana-1928, determina em seu artigo $1^{\circ}$ que "os Estados têm o direito de estabelecer, por meio de leis, as condições de entrada e residência dos estrangeiros nos seus territórios".

$\mathrm{Na}$ República Federativa do Brasil, inserto no artigo 22, XV da Constituição Federal $^{4}$ temos que a União mantém sua competência para legislar sobre a entrada e expulsão de estrangeiros e, portanto, para conceder e manter a permanência destes em solo pátrio. Outrossim, prevê a Carta Maior em seu artigo $5^{\circ}, \mathrm{XV}$ que "é livre a locomoção no território nacional em tempo de paz, podendo qualquer pessoa, nos termos da lei| [grifo nosso], nele entrar, permanecer ou dele sair com seus bens". A lei que regulamenta a citada livre locomoção é o Estatuto do Estrangeiro. $^{5}$

Destarte aqueles estrangeiros que por qualquer motivo não se adequarem às referidas condições estipuladas, seja de entrada seja de permanência no país estarão sujeitos a sua retirada compulsória através da expulsão por cometimento de atos prejudiciais ao Estado, extradição por cometimento de crime em outro Estado e por este ser requerida sua entrega, ou deportação pela entrada ou permanência ilegal no país, dependendo então da espécie de prescrição legal desacatada.

Em resumo diferem-se os três institutos por ser a extradição a saída compulsória, de estrangeiro ou nacional naturalizado em razão de pedido de outro Estado por estar o sujeito sendo

2 ACCIOLY, Hildebrando; NASCIMENTO E SILVA, G.E. Manual de direito internacional público. 14. ed. São Paulo: Saraiva, 2000, 364 p.

3 "Extradición es el acto en cuya virtud un estado hace entrega, a requerimiento de outro, de un individuo inculpado, para su julgamiento o condena." QUINTA, Lúcio M. Moreno; SHAW, Carlos M. B. Derecho Internacional Público. Aires: Libreria del Colégio, 1950; p. 157. 4 Caberá exclusivamente ao presidente da República resolver sobre a conveniência e oportunidade da expulsão ou de sua revogação. A medida expulsória ou a sua revogação far-se-á por decreto.

5 Lein 6.815/80, art. 57. 
acusado ou já condenado pela prática de crime no país requerente. A exclusão ocorre por iniciativa de outro Estado. Já a expulsão e a deportação consistem na retirada compulsória de estrangeiro do território nacional por iniciativa local, sendo a expulsão ato discricionário do governo brasileiro diante do cometimento pelo indivíduo alienígena de atos entendidos como nocivos à segurança e à tranqüilidade da nação. A medida de deportação, por sua vez, tem como escopo a proteção do Estado com a exclusão compulsória do estrangeiro que no país adentrou ou permaneceu à revelia das exigências para tal conduta.

Com a evolução natural do mundo reunido cada vez mais em blocos se faz necessário o uso de uma forma eficaz para o combate de crimes que acompanham essa evolução global. Neste contexto, a extradição tem se mostrado eficiente instrumento de cooperação internacional no combate à impunibilidade de criminosos que buscam furtar-se das malhas da lei simplesmente ultrapassando fronteiras geográficas. Por essa razão justificase o interesse no estudo desse instituto, que é próprio do direito internacional, mas que está inserido no direito interno, de todos os países.
Essa análise será feita em duas partes. A primeira trata dos fundamentos da extradição no direito brasileiro, apresentando um estudo dos seus fundamentos internacionais e nacionais, a segunda trata da concessão da extradição no direito brasileiro explanando os requisitos formais, bem como os requisitos materiais, todos constantes da lei $n^{\circ} 6.815 / 80$.

\section{OS FUNDAMENTOS DA EXTRADIÇÃO NO DIREITO BRASILEIRO}

O instituto da extradição é um dos mecanismos jurídicos destinados a promover a paz social, portanto seu fundamento geral está na cooperação solidariedade que deve reinar entre todos os membros da comunidade internacional, os quais têm necessidade de reprimir os atos delituosos, visando com esse intercâmbio de relações promover o equilíbrio social nos Estados. ${ }^{6}$

As primeiras idéias sobre a extradição no direito brasileiro datam do século XIX - década de 1820 - quando o Brasil celebrou vários tratados em matéria extradicional, como com a Alemanha, França, Inglaterra, Portugal e Rússia, que permitiam a extradição por crimes como rebelião do vassalo

\footnotetext{
6 Essa intenção é manifesta em todos os preâmbulos de tratados de extradição firmados pelo Brasil, dentre os quais citamos com os Estados Unidos da América: "Os Estados Unidos do Brasil e os Estados Unidos da América, desejando tornar mais eficaz a cooperação dos respectivos países na repressão ao crime, resolvem celebrar Tratado de Extradição e, para esse fim, nomearam os seguintes Plenipotenciários."
} 
contra o seu senhor, a deslealdade, a perfídia, a traição, a produção de dinheiro falso além de outros delitos que contrariavam as normas de ordem sóciocultural da época. O primeiro pedido de extradição dirigido ao Brasil data de quatro de março de 1845 , de procedência da França, com desfecho ignorado. O ato era puramente administrativo, o poder judiciário não intervinha, o governo prendia e entregava o extraditando.

Foi a circular de quatro de fevereiro do ano de 1847 que estabeleceu os princípios e as considerações gerais de entrega de criminosos refugiados no Brasil, prevendo as condições que seguem:

a) Quando os crimes pelos quais se reclamar a extradição tiverem sido cometidos no território do governo reclamante, e este oferecer ou se prestar à reciprocidade; b) Quando pela gravidade e habitual frequiência forem capazes de pôr em risco a moral e a segurança dos povos, tais como os de roubo, assassínio, moeda falsa, falsificações e alguns outros; c) Quando estiverem provados de maneira que as leis do Brasil justifiquem a prisão e acusação, como se o crime tivesse sido nele cometido; d) Quando o suspeito ou criminoso for reclamado pelo ministro da nação em que tiver lugar o delito e, e) Se o mesmo indivíduo for criminoso em mais de um Estado e for reclamada sua entrega em cujo território tiver sido cometido o mais grave delito.

A circular de 1847 foi revogada pelo Barão de Cairu e exarada nova circular em dez de agosto de 1848. A importância da circular de 1847 está no fato de ter sido baseado nela que o Brasil celebrou muitos tratados e declarações de reciprocidade.

Já no início do Século XX em 1906 o poder judiciário passou a se posicionar de forma ativa nos processos de extradição, contestando a competência do Poder Executivo na concessão dos pedidos extradicionais, não só baseados em tratados internacionais, mas apenas em acordos de reciprocidade de tratamento, e assim abandonou a postura de neutralidade para avocar-se a competência para a concessão dos pedidos.

A primeira lei de extradição do País foi a de $n^{\circ} 2.416$ de 28 de junho de 1911 . Posteriormente surgiu o decreto-lei $\mathrm{n}^{\circ}$ 394, de 28.4.1938, que vigorou até 1969 e assim sucederam-se os decretos e leis até a vigência do Estatuto do Estrangeiro - lei $n^{\circ} 6.815 / 1980$ que define a situação jurídica do estrangeiro no Brasil e criou o Conselho Nacional de Imigração, alterada pela lei n ${ }^{\circ} 6.964$ / 1981 , e regulamentada pelo decreto $\mathrm{n}^{\circ} 86.715 / 1981$.

\section{Fundamento internacional}

A Declaração Universal dos Direitos do Homem, no seu artigo XI manifesta que "todo homem acusado de um ato delituoso tem o direito de ser presumido inocente até que a sua culpabilidade tenha sido provada de acordo com a lei, em julgamento público no qual the tenham sido 
asseguradas todas as garantias necessárias à sua defesa".

No caso específico da extradição, a lei $n^{\circ} 6.815 / 1980$, art. 76 , prevê que seja fundada em tratado ou reciprocidade, que será tratada a seguir. ${ }^{7}$ Nos dizeres da renomada Gilda Russomano os tratados de extradição são: Acordos celebrados entre Estados, através dos quais eles estabelecem regras para a entrega recíproca dos delinqüentes que tenham praticado o delito no território de um deles e se refugiado dentro das fronteiras do outro. ${ }^{8}$

Geralmente a concessão da extradição de um indivíduo é praticada de conformidade com um tratado que pode ser bilateral ou multilateral, assinado pelos Estados envolvidos, no qual se estabeleça que na conformidade de certos pressupostos, dar-se-á a entrega do indivíduo requisitado. Apresentam seu fundamento nos princípios do pacta sunt servanda, que é um dos princípios constitucionais da sociedade internacional, e do pacta tertiis nec nocent prosunt, já que têm efeitos contra terceiros.
Silbert apresenta algumas características primordiais para estes tratados, a saber:

a) "Precisam as condições e as formalidades da extradição, evitando dúvidas e incertezas"; b) "Protegem os Estados fracos das pressões, muitas vezes injustificadas, dos Estados fortes"; c) "Constituem medida preventiva do delito pela advertência que fazem aos criminosos eventuais, lembramo-nos de que, dificilmente se poderão refugiar na impunidade ou escapar às conseqüências de seus atos". 9

Terão efeito vinculatório para os contratantes e o tratado mais recente revogará o mais antigo firmado pelas partes, além disso, seu teor consiste, via de regra, em estipular os pressupostos legais para a extradição, como o delito ser tipificado em ambas as legislações internas dos Estados contratantes, a enumeração dos crimes que justificam o pedido. Mas a maioria dos internacionalistas entende que deve ser subentendido que a enumeração dos delitos é puramente exemplificativa, não

\footnotetext{
7 Acto judicial transcendente, la extradición solo procede mediante tratado sobre la matéria entre estado requirente y estado requerido. La cortesia o la reciprocidad motivan a veces, la extradición (comitas gentium ad reciprocicam utilitatem) lo cual no la convierte en obligacion jurídica. (Quintana, Lucio Moreno e Carlos M.B. Shaw. Derecho Internacional Publico. Ediciones Libreria del Colégio. Buenos Aires; 1950, p. 157).

8 TAGLIANI, Camila Carneiro. A extradição no ordenamento juridico brasileiro. São Paulo: Memória Jurídica. 2002. p. 42-43.

9 Citado por Gilda Russomano in A Extradição no Direito Internacional e no Direito Brasileiro. 3. ed.; SP: Revista dos Tribunais, 1981.
} 
excluindo outros crimes, ${ }^{10}$ os requisitos de ordem formal que devem instruir o pedido, e.g. os documentos probatórios da existência de um processo criminal em andamento ou sentença condenatória," que o crime não tenha cunho político em ambos os Estados; que a pena imposta seja superior a um ano de prisão, bem como a estipulação das regras para a solução de quaisquer litígios decorrentes do tratado, e.g. o art. 19 do Tratado entre Brasil e Argentina: Todas as divergências entre as Altas Partes Contratantes, relativas à interpretação ou execução deste Tratado, se decidirão pelos meios pacíficos reconhecidos no Direito internacional.

No que concerne a eficácia, o STF já decidiu' ${ }^{12}$ que os tratados de extradição têm aplicação imediata, independentemente de o crime em que se funda a extradição ser anterior a ele, salvo disposição expressa em contrário.

A extradição na América Latina é abordada em vários tratados internacionais multilaterais, como a Convenção sobre Extradição - Montevidéu, 1932 - que modificou o Código de Bustamante - 1928 e o Tratado de Direito Penal Internacional (Montevidéu -
1940). Além destes existem a Convenção de Haia e de Tóquio para combate à pirataria séria e o Acordo de Extradição entre os Estados partes do Mercosul, a República da Bolívia e a República do Chile, firmado em 20 de novembro de 1998.

O Brasil é signatário de vários tratados bilaterais para extradição que têm sido efetivamente aplicados. A ausência de tratado de extradição entre o Estado de refúgio e o que solicita a entrega do delinqüente não será motivo suficiente para a denegação do pedido. Nessa situação utilizar-se-á o mecanismo da reciprocidade.

A reciprocidade é definida como a permissão do Estado em admitir a execução de sentenças estrangeiras, se o país de onde provêm admitir execução das decisões nacionais ou uma declaração segundo a qual, ocorrendo crime análogo no país requerido, o país requerente se compromete a conceder a extradição solicitada.

Segundo o mestre Francisco Rezek, as declarações de reciprocidade, em matéria de extradição, tendem a instituir entre Estados uma relação jurídica diversa da relação convencional. O vínculo da

10 e. g.: o artigo 13 do código penal uruguaio que permite a extradição por crimes não previstos expressamente no tratado existente: La extradición puede otorgar-se u ofrecerse aún por delitos no contemplados en los tratados, siempre que no existiera prohibición en ellos.

11 Tratado de extradição firmado pelo Brasil e pela Suíça: "O pedido de extradição será feito por via diplomática."

12 STF - Pleno Extradição nº 759 - Itália; Rel. Min. Moreira Alves, decisão 9/12/1999. 
reciprocidade não é um tratado bilateral sui-generis, como já se viu insinuar. ${ }^{13}$

A reciprocidade foi utilizada pela legislação brasileira desde os primórdios do instituto com a Circular de 4 de fevereiro de 1847 que teve grande importância para o desenvolvimento do mecanismo da extradição porque estabeleceu os princípios e as condições gerais para a entrega de extraditandos pelo Brasil, dentre elas a previsão de reciprocidade: Quando os crimes pelos quais se reclamar a extradição tiverem sido cometidos no território do governo reclamante, e este oferecer ou se prestar à reciprocidade. A partir dessa Circular o Brasil celebrou vários tratados bilaterais e declarações de reciprocidade, destacando-se os tratados de 1851 com o Uruguai, 1853 com o Peru, 1855 com o Equador, 1857 com Portugal e com a Argentina.

A reciprocidade opera stricto sensu, consistindo no pedido de um Estado a outro a entrega de um nacional seu ou não que esteja no mínimo sendo acusado do cometimento de um crime comum nos seus domínios, prometendo acolher, no futuro, pedidos que transitem em sentido inverso. Assim a reciprocidade não compreende condições especiais na sua feição, como a exposição de certas exceções a delitos ou outros requisitos normais à extradição, pois se assim fosse teríamos um tratado bilateral de extradição e não um compromisso de reciprocidade. Esse deve ser o mais puro e direto possível.

A relação que se estabelece entre dois Estados por força do sistema de reciprocidade difere da que caracteriza os tratados bilaterais. Estes devem possuir forma escrita, elementos de natureza contratual e têm duração indefinida, já o elo da reciprocidade dispensa textos escritos, sendo mesmo incorpóreos, têm origem em um fato concreto (a necessidade de um pedido de extradição) e materializam-se através de nota diplomática. ${ }^{14} \mathrm{O}$ compromisso tem efeito de criar obrigação entre as partes. É uma liberalidade estabelecer reciprocidade ou não com outro Estado, mas uma vez acordado gera obrigações. Dessa forma, o dever de garantir adequado exame jurídico à demanda da outra parte refoge ao terreno da pura cortesia internacional, bem assim ao domínio do direito interno. Descumprir esse dever é incidir em ilícito internacional. Neste caso buscase a aplicação do Direito das Gentes, que protege com eficiência o compromisso de reciprocidade.

Existem muitos pedidos de extradições autorizadas pelo Brasil com

13 Direito dos Tratados. São Paulo: Saraiva, p. 168.

14 Quando se cuida de estabelecer o vínculo de reciprocidade, uma nota diplomática contendo a promessa de igual tratamento acompanha o pedido concreto de extradição. 
fundamento em compromisso de reciprocidade. ${ }^{15}$

\section{Fundamento nacional}

No âmbito do Direito Pátrio a extradição tem fundamento na Constituição e em leis esparsas.

A extradição alicerçada no espírito de cooperação mútua entre os povos para repressão ao crime tem seus fundamentos legais de ordem internacional, tratado e declaração de reciprocidade, conforme já foi visto e os fundamentos nacionais, no ordenamento jurídico brasileiro, tema que abordaremos neste capítulo.

A nacionalidade é o vínculo jurídicopolítico que liga o indivíduo ao Estado. Desde as primeiras práticas da extradição na história brasileira sua fonte preponderante eram os tratados internacionais, mas atualmente temos sua cominação na Constituição Federal e leis esparsas.

Para o deferimento do pedido de extradição de estrangeiro ao Brasil o Estado requerente deve fundar seu pedido nas hipóteses constitucionais (requisitos materiais: art. $5^{\circ} \mathrm{LI} \mathrm{e} \mathrm{LII)} \mathrm{e}$ nas normas legais esparsas (requisitos formais: Estatuto do Estrangeiro, Lei Federal $n^{\circ} 6.964 / 81$ e Regimento Interno do Supremo Tribunal Federal).

A extradição se divide em duas espécies: ativa, aquela requerida pelo Brasil a outros Estados soberanos e a passiva, que é a que se requer ao Brasil por outro Estado.

Os requisitos e restrições constitucionais e esparsas na legislação ordinária incidem somente nos pedidos de extradição passiva, ou seja, quando o Brasil é o país requerido - incitado a entregar criminosos.

15 Pedido de Extradição n 272-4 - República Federal da Áustria, República Popular da Polônia e República da Alemanha. Rel.: Min. Vítor Nunes Leal. Extradição. O deferimento ou recusa da extradição é direito inerente à soberania. A efetivação, pelo governo, da entrega do extraditando, autorizada pelo STF, depende de direito internacional convencional. Reciprocidade. É fonte reconhecida do direito extradicional. Extr. 232 (1961), Extr. 288 (1962), Extr. 251 (1963). A Constituição de 1967 art. 83, VIII, não exige referendum do Congresso para aceitação da oferta do Estado requerente. A lei brasileira autoriza o governo a oferecer reciprocidade.

Pedido de extradição ${ }^{\circ} 347$ - Itália. Relator: Min. Djaci Falcão. Pedido de extradição sob promessa de reciprocidade de tratamento. Mandato di cattura, medida cautelare coercitiva, que equivale à prisão preventiva prevista na legislação brasileira. Imputação dos crimes de corrupção ativa e truta qualificada. Tipicidade penal incontroversa

Pedido de extradição n 378 - República da Áustria. Relator: Min. Xavier de Albuquerque. Extradição. Crimes patrimoniais imputados a um casal. Narrativa que só deixa caracterizada, de modo aceitável, a conduta delituosa do varão (esteleionato sob a forma de venda de coisa alheia como própria). Prazo de diligência observado. Pedido parcialmente deferido. Relatório: Garantindo reciprocidade de tratamento, o Governo da República da Áustria pede a execução. 
O artigo $5^{\circ}$, LI e LII da Carta Magna disciplina a extração. Está, portanto inserta dentre as garantias fundamentais da pessoa.

É possível se depreender dos incisos retro mencionados que a Constituição Federal prevê tratamento diferenciado aos brasileiros natos, naturalizados e aos estrangeiros a respeito da extradição. Vejamos:

- O brasileiro nato nunca será extraditado;

- O brasileiro naturalizado somente será extraditado em dois casos: por crime comum, praticado antes da naturalização ou quando da participação comprovada em tráfico ilícito de entorpecentes e drogas afins, na forma da lei, independentemente do momento do fato, não importa se foi antes ou depois da naturalização.

É absoluta a inextradibilidade de cidadão brasileiro nato assim como a maioria das legislações internacionais contemporâneas. Todavia grande parte da literatura jurídica internacional atual é favorável à extradição de nacionais. Poucos Estados, no entanto, a concedem, e quando o fazem é submetida à condição de reciprocidade como os Estados Unidos da América, a Grã-Bretanha e a Itália. ${ }^{16}$

A respeito da discussão sobre a inextradibilidade de nacionais é válido ressaltar a ponderação do eminente Hildebrando Accioly: "Os Estados devem proteção a seus nacionais e, por conseguinte, têm a obrigação de lhes garantir uma justiça imparcial; ora, essa imparcialidade pode faltar aos juízes estrangeiros. Os Estados não devem abdicar parcela alguma e sua soberania," e a entrega de um nacional a uma justiça estrangeira constitui uma espécie de renúncia a direitos inerentes à soberania. Todo indivíduo tem o direito de viver no território sob a proteção do Estado de que é nacional, e, portanto, seria injusto afastá-lo contra a vontade. Esses argumentos podem ser facilmente rebatidos. Primeiro de tudo, a proteção devida pelo Estado aos seus nacionais não pode ser entendida de maneira que impeça o comparecimento destes perante juízes estrangeiros". ${ }^{17}$

Defensores da extradição de nacionais argumentam ainda que o princípio da territorialidade da lei penal, pelo qual o julgamento do criminoso compete ao país que teve sua norma penal infringida. Esta argumentação é fundada na questão prática da dificuldade da produção de provas em Estado diverso daquele onde houve o cometimento do fato delituoso. Filiamse a esta corrente, países como o Uruguai, a Colômbia, a Grã-Betranha e os Estados Unidos.

160 princípio da não extradição de nacionais não é recente, remonta ao séc. XII, e resulta do dever de proteção do Estado aos seus cidadãos.

17 Extraído da revista Informação Legislativa a.19, n. 76/out/dez., 1982, p. 73. 
O Brasil não extradita brasileiros natos sendo relativa essa regra quanto aos naturalizados.

A naturalização, que para muitos é um ato de soberania do Estado e, portanto, de natureza política e de total discricionariedade, é o meio tradicional de aquisição derivada da nacionalidade brasileira. A Constituição Federal prevê dois parâmetros para a concessão do pedido quanto aos naturalizados: a) a época da naturalização e, b) a natureza do crime cometido.

a) Será extraditado brasileiro naturalizado, em caso de crime comum, praticado antes da naturalização.

Todas as Constituições brasileiras até 1946 faziam distinção entre brasileiros natos e naturalizados. A de 1988 trouxe clara distinção para os efeitos da extradição. A aquisição da nacionalidade brasileira após o cometimento de crime comum tem por efeito a nulidade do ato de naturalização, em razão da presunção de que a naturalização só foi pedida com o desiderato de impedir a aplicação da pena prevista para o crime. Neste sentido a doutrina de Pontes de Miranda ao esclarecer que: pedida a extradição do estrangeiro, isto é, do naturalizado brasileiro, por fato anterior à naturalização, a extradição pode ser concedida, se a naturalização não podia ser deferida (nulidade com efeito ex tunc), porquanto que o tivesse sido. ${ }^{18}$

b) Será extraditado brasileiro naturalizado, comprovado seu envolvimento em tráfico ilícito de entorpecentes e drogas afins, independentemente do momento da prática desse crime ter sido antes ou depois da naturalização. ${ }^{19}$

Assim, se para quaisquer outros crimes exige a Constituição o fator anterioridade da naturalização, para a proteção do Estado brasileiro, no caso do tráfico de entorpecentes e drogas afins, devido a sua gravidade e mobilização da comunidade internacional para seu refreamento, não vale o elemento tempo de naturalização para refugiar-se no solo pátrio o meliante. Neste sentido esta redação constitucional objetiva combater com maior rigor o crime de tráfico, que tem se alastrado por todo o mundo de forma veloz e eficaz. Porém, este dispositivo não é suficientemente aplicável, eis que, na forma da lei pressupõe que a legislação ordinária deverá regulamentar a forma de aplicação da norma constitucional. Isto significa que o artigo $5^{\circ}, \mathrm{LI} d a$ CF/88 não é auto-aplicável. Além disso, não existe legislação ordinária regulamentando esta situação. ${ }^{20}$

18 Comentários a Constituição de 1967, t.5, p. 258.

19 MORAIS, Alexandre de. In Direito Constitucional; 12. ed. São Paulo: 2002, p. 114.

20 Op. cit. p. 14. CARNEIRO, Camila T. in A Extradição no Ordenamento Jurídico Brasileiro. São Paulo: Memória Jurídica, 2002, p. 57. 
A aplicação desse inciso encontra dificuldades na prática. O ordenamento brasileiro adota o sistema da contencionalidade limitada no qual não cabe ao Estado requerido analisar o mérito do processo que ensejou o pedido de extradição, cabendo apenas analisar o aspecto formal. Ora, a Constituição Federal fala em "comprovado envolvimento" no ilícito de tráfico de entorpecentes e "na forma da lei", são exigências de caráter excepcional, e não formais.

Destarte, não havendo permissão para análise do mérito e inexistindo lei regulamentadora para o inciso torna-se difícil sua aplicação. Para solucionar esta problemática o Supremo admite a extradição nos casos em tela, se o pedido vier instruído com provas de envolvimento do extraditando em crime de tráfico de drogas, com sentença condenatória transitada em julgado.

O entendimento do Supremo Tribunal Federal sobre a extradição por crime político é o seguinte: é de repelirse, no caso concreto, a existência de crime político, dado que não é demonstrada a destinação de atentar, efetiva ou potencialmente, contra a soberania nacional e a estrutura política. ${ }^{21} \mathrm{De}$ acordo com este raciocínio lógico, o português que goza de todos os direitos do brasileiro naturalizado, conforme 0 parágrafo $1^{\circ}$ do artigo 12 da $\mathrm{CF} / 88$, poderá ser extraditado como brasileiro naturalizado. Todavia é resguardado por certas prerrogativas decorrentes de tratado bilateral firmado entre a pátria brasileira ePortugal-Decreto Legislativo $n^{\circ} 70.391 /$ 72 o qual restringe a possibilidade de cidadão português equiparado ser extraditado somente para Portugal.

Várias foram as normas infraconstitucionais que regulamentaram a extradição até as vigentes de hoje.

Em 1808, com a vinda da família real portuguesa para o Brasil e a abertura dos portos brasileiros ao comércio houve um aumento substancial no fluxo de estrangeiros entrando no país; assim, surgiu a necessidade de uma norma a tratar da extradição: a Circular de 4 de fevereiro de 1847 , expedida pelo Ministério dos Negócios Estrangeiros, chefiado pelo Barão de Cairu, sendo o primeiro documento brasileiro sobre o instituto e continha regras gerais para a entrega de estrangeiro por crime cometido no exterior.

Em 1848, 10 de agosto, o mesmo Barão de Cairu exarou nova circular sobre a extradição, revogando a de 1847. Todavia, como o documento de 1848 não atendeu as necessidades existentes, a circular de 1847 foi repristinada, tendo vigência até $1911 \mathrm{com}$ a publicação da lei $n^{\circ} 2.416(28 / 06)$, caracterizada pela permissão da extradição de nacionais brasileiros (artigo $1^{\circ}$ ).

Já a lei $\mathrm{n}^{\circ} 2.416$ foi revogada pelo decreto-lei $n^{\circ} 394$ de 28 de abril de 1938 que veio a proibir a extradição

21 STF $2^{\text {a }}$ t.-HC no 73.452/RJ - Rel. Min. Maurício Correa, Diário da Justiça - Seção I, 27 / junho 1997, p. 30.226 . 
de brasileiros natos, sob o princípio da proteção que o Estado deve conceder aos seus nacionais. Este decreto-lei foi revogado pelo de $n^{\circ} 941$ - Estatuto do Estrangeiro, datado de 13 de outubro de 1969, revogando integralmente a legislação editada de 1938 , no que concerne à extradição. A lei $n^{\circ} 6.815$, de 19 de agosto de 1980, revogou o Estatuto de 1969, passando a disciplinar a matéria de extradição no Brasil.

O Brasil é signatário de vários tratados internacionais para extradição - como o Código de Bustamante, concluído na $6^{\mathrm{a}}$ Conferência PanAmericana de Direito Privado, no ano de 1928 - contendo 38 artigos sobre o instituto; a Convenção Interamericana sobre Extradição, firmada em Caracas no ano de 1981. No âmbito do Mercosul, não há ainda regulamentação específica sobre a extradição; em vigência apenas o Protocolo de Assistência Jurídica Mútua em Assuntos Penais do Mercosul.

Assim, além dos protocolos internacionais, são normas infraconstitucionais em vigência no país em matéria de extradição e Estatuto do Estrangeiro - lei $\mathrm{n}^{\circ} 6.815 / 80$, artigo 91 e seguintes; a lei federal $n^{\circ} 6.964 / 81$ e o Regimento interno do Supremo Tribunal Federal, artigos 207 a 214.

\section{A CONCESSÃO DA EXTRADIÇÃO NO DIREITO BRASILEIRO}

A extradição - instrumento de garantia da ordem social na comunidade internacional - ainda apresenta discussão a respeito de sua natureza jurídica. Entendem alguns juristas que se trata de um ato administrativo discricionário do governo, sem garantia jurisdicional para o extraditando, e outros, que é ato de natureza jurisdicional entre o Estado requerente e o extraditando, procedimento que finaliza com sentença vinculadora para o Estado requerido.

No Brasil, assim como na Itália, adota-se o sistema misto, no sentido de que o processo extradicional é um ato de governo, mas subordinado a uma garantia jurisdicional em favor do extraditando.

A Constituição Federal brasileira prevê em seu artigo 102, I "g", que a competência originária para processar e julgar pedido de extradição é resguardada à cúpula maior do poder judiciário brasileiro, o Supremo Tribunal Federal:

Artigo 102 - Compete ao SFT, precipuamente, a guarda da Constituição, cabendo-lhe:

I - processar e julgar, originariamente:

" $g$ " - a extradição solicitada por Estado estrangeiro.

Em que pese ser a extraditio no Brasil um procedimento bifásico, que tem seu início em mãos do poder executivo e processo e julgamento nos domínios do poder judiciário, é cabível um estudo mais aprofundado acerca de sua competência e procedimento. É o que examinaremos a seguir. 


\section{A) Condições formais}

1. Da competência do Supremo Tribunal Federal

Sendo que a Constituição Federal confere a competência para análise da legalidade e procedência do pedido extradicional à mais alta corte do poder judiciário, é nele - Supremo Tribunal Federal - que se exercem todos os trâmites legais em relação à extradição. ${ }^{22}$

Assim dispõe o artigo 83 da lei vigente que:

Art. 83 - Nenhuma extradição será concedida sem prévio pronunciamento do plenário do Supremo Tribunal Federal sobre sua legalidade e procedência, não cabendo recurso da decisão.

Além deste, determinam a competência originária do STF os artigos 102, I, "g" da Constituição Federal (já citado) e o artigo 207 do Regimento Interno do STF:

Art. 207 - Não se concederá extradição sem o prévio pronun- ciamento do STF sobre a legalidade e a procedência do pedido, observada a legislação vigente.

Uma leitura sumária dos dispositivos legais supracitados pode conduzir a interpretação equivocada de que a Corte Suprema brasileira possui poderes absolutos para analisar todos os aspectos do pedido de extradição. Todavia tais poderes são, em verdade limitados à análise das circunstâncias legais e formais do pedido, vedada a análise do mérito do fato ensejador. É o que denominamos contencionalidade limitada.

É o sistema de competência judiciária, desde que quem concede a extradição não é o poder judiciário, mas sim executivo, e ao judiciário compete apenas dizer da legalidade do pedido.

Nos dizeres de José Francisco Rezek explicando o artigo 85, parágrafo $1^{\circ}$ do Estatuto do Estrangeiro, a defesa do extraditando não pode adentrar o mérito da acusação: ela será impertinente em tudo quanto não diga respeito à sua identidade, à instrução do pedido ou à ilegalidade da extradição à luz da

22 A prática internacional sobre essa matéria não é uniforme. O sistema francês tem caráter essencialmente político e deixa a extradição ao arbítrio do poder executivo, sem nenhuma garantia jurisdicional em favor do extraditando. A intervenção, requerida pelo Conselho de Estado e pela autoridade judicial tem caráter meramente consultivo. Por outro lado, os sistemas inglês e norte-americano revestem-se de caráter de procedimento jurisdicional, no qual o Estado requerente e a pessoa extraditanda são partes, e a sentença pertinente não poderá ser executada enquanto não passar em julgado. $O$ sistema belga-holandês, de caráter jurisdicional, faculta ampla liberdade aos interessados. 
lei específica. ${ }^{23}$ Neste sentido é vasta a jurisprudência do $\mathrm{STF}^{24}$

Destarte será o Supremo proibido de apreciar o mérito no processo de extradição passiva brasileira.

O procedimento do pedido de extradição com base em processo penal em curso ou sentença condenatória é feito pelo governo do Estado requerente através da via diplomática e endereçado ao presidente da república - chefe do poder executivo - que é a autoridade com autorização constitucional para manter relações com Estados estrangeiros (art. 84, VII CF). Essa negociação tem, portanto, caráter intergovernamental. ${ }^{25}$

A lei brasileira dispõe que ninguém será extraditado sem que o processo seja analisado pelo poder judiciário, porém, o Supremo Tribunal Federal não concede a extradição, mas sim, autoriza o executivo a fazê-lo. ${ }^{26}$ Salienta-se que no caso de denegação do pedido, o Estado requerente não poderá repeti-lo fundado no mesmo fato, conforme prevê o art. $88 \mathrm{da}$ Lei $\mathrm{n}^{\circ} 6.815 /$ 80 . Uma vez decidido pela procedência da entrega do extraditando, será o fato comunicado por via do Ministério das Relações Exteriores ao Estado requerente que então disporá de um prazo peremptório de sessenta dias (salvo disposição distinta em tratado), para resgatá-lo do território brasileiro, sob pena de livrar-se solto o extraditando.

Os requisitos formais e materiais apreciados pelo Supremo para a

23 Op.cit. p.7, in Direito Internacional Público - Curso Elementar. São Paulo: Saraiva, 1998, n. 118, p. 202.

24 Extradição n ${ }^{\circ} 659-2$. Rel. Min. Marco Aurélio. Extradição - Matéria de defesa - Inexistência de configuração do crime imputado. Na apreciação do pedido de extradição descabe o exercício de crivo relativamente à procedência, ou não, da imputação formalizada no Estado requerente. Cumpre tão só verificar a observância dos requisitos previstos no artigo 88 da Lei $\mathrm{n}^{\circ} 6.815 / 80 \mathrm{e}$ a inexistência de qualquer dos óbices revelados no artigo 77 do citado diploma. (DJ de 15.03.1996).

25 Extradição. Pressuposto. Competência. 1. É pressuposto essencial da extradição que seja ela requerida por Governo de país estrangeiro. Pedido não conhecido, visto que formulado por autoridade judiciária estrangeira. O pedido é encaminhado para o STF que providenciará a prisão preventiva, conforme exigência do art. 81 do Estatuto do Estrangeiro, do extraditando decretada pelo Ministro Relator, que ficará prevento para a condução do processo extradicional. Preso o extraditando, tem início o processo que possui caráter especial, sem dilação probatória, pois incumbe ao Estado requerente o dever de instruir o processo, apresentando prova pré-constituída de natureza documental essencial em face aos requisitos constitucionais. Os documentos instrutórios do pedido constam no art. 80 da Lei $n^{\circ} 6.815 / 80$ e específica no art. $85, \S 2^{\circ}$ que não estando 0 processo devidamente instruído, o tribunal poderá converter o feito em diligências para suprir as provas.

26 Op.cit. p. 14, CARNEIRO, Camila T. in A Extradição no Orndenamento Jurídico Brasileiro. São Paulo: Memória Jurídica, 2002, p. 81. 
concessão do pedido são os constantes na Lei $n^{\circ} 6.815 / 80$, art. 77 , por critério de exclusão, já que mencionam as circunstâncias em que não se deferirá a extradição, a saber:

I - se tratar de brasileiro, salvo se a aquisição dessa nacionalidade verificar-se após o fato que motivar o pedido;

II - o fato que motivar o pedido não for considerado crime no Brasil ou no Estado requerente;

III - o Brasil for competente, segundo suas leis, para julgar o crime imputado ao extraditando;

IV - a lei brasileira impuser ao crime a pena de prisão igual ou inferior a um ano;

$V$ - o extraditando estiver a responder a processo ou já houver sido condenado ou absolvido no Brasil pelo mesmo fato em que se fundar o pedido;

$V I$ - estiver extinta a punibilidade pela prescrição segundo a lei brasileira ou a do Estado requerente;

VII - o fato constituir crime político;

$e$,
VIII - o extraditando houver de responder, no Estado requerente, perante tribunal ou juizo de exceção.

Devido à importância desses requisitos legais para a concessão da extradição analisaremos a seguir sua interpretação e aplicação pelo Supremo Tribunal Federal.

\section{B) Condições materiais}

Passaremos a examinar cada uma das regras materiais estabelecidas na legislação infraconstitucional para a concessão do envio.

\section{Da competência brasileira para o julgamento do crime}

Inculta no art. 77, III do Estatuto do Estrangeiro está a vedação da concessão da extradição nos casos em que o Brasil for competente, segundo suas leis, para julgar o crime imputado ao extraditando.

Conforme a interpretação do dispositivo o Brasil concederá a extradição quando configurar competência penal exclusiva da justiça do Estado requerente para processar e julgar o fato, do qual decorre incompetência do Brasil. Assim se a legislação pátria prevê que o Brasil tem competência privativa para julgar o crime que deu origem ao pedido extradicional, este será denegado, e se a competência para julgamento for concorrente entre o Brasil e o país requerente e o 
extraditando já estiver sendo processado no Brasil, não será concedida a extradição. ${ }^{27}$

Se o contrário ocorrer, o conjunto de provas que instruiu o pedido de extradição servirá para instruir o processo que aqui deva ter curso no foro criminal, conforme assevera Rezek que informa também que o Supremo vem abrandando o rigor da regra, $\mathrm{e}$ preferindo conceder a extradição hotadamente a de tráfico de drogas quando não se tenha ainda instaurado no Brasil algum processo pelos mesmos fatos, ainda que lhes pareça aplicável, em princípio, nossa lei penal. ${ }^{28}$

No que concerne à competência concorrente a interpretação do Supremo é de que mesmo existindo competência relativa do Brasil para o processo e julgamento do fato se aqui não houver um inquérito policial ou processo penal em andamento será deferida a extradição.

\section{Da vedação do Juízo de} Exceção

É regra no direito das gentes não se utilizar tribunal ou juízo de exceção para processar e julgar criminosos. Todavia já se vislumbrou esta prática no século XX após a Segunda Guerra Mundial, no final da década de 1940, com os tribunais na cidade alemã de Nuremberg, para processar e julgar os crimes de guerra e contra a humanidade cometidos pelo $3^{\circ}$ Reich, durante a Grande Guerra. A maioria dos condenados na época que em defesa argumentaram a nulidade dos julgamentos devido à sua natureza excepcional, já que foi instituído pós factum, lograram êxito.

O Direito das Gentes um de cujos princípios é o respeito aos direitos humanos não admite juízo de exceção e o Estatuto do Estrangeiro em seu art. 77, VIII, traz expressa a vedação da

27 Op.cit. p. 14, CARNEIRO, Camila T. in A Extradição no Orndenamento Jurídico Brasileiro. São Paulo: Memória Jurídica, 2002, p. 73.

28 Op.cit. REZEK, José Francisco. in Direito Internacional Público. São Paulo: Saraiva, 1998,410 p. Extradição n ${ }^{\circ}$ 695-9. Rel. Min. Celso de Mello. Extradição - Tráfico de drogas - Exportação de cocaína do Brasil para a Itália - Concurso de jurisdições penais - Ausência de inquérito policial, ou de processo penal no Brasil, possibilidade de efetivação da entrega extradicional - Discussão de matéria probatória e alegação de inocência do extraditando - Inadmissibilidade - Sistema de Contecionalidade Limitada - Pedido deferido. (DJ 02.02.1997). Extradição. Mandado de prisão. Integralidade. Competência concorrente da Justiça do Estado requerente. Documentação. Estatuto do Estrangeiro: Lei ${ }^{\circ} 6.815 / 80$, modificada pela Lei $n^{\circ} 6.964 / 81$. Extraditando casado com brasileira e com filhos brasileiros. Súmula 421 . Não procede, no caso, a objeção à competência exclusiva da Justiça brasileira para o processo criminal, não só pelo princípio da universalidade, por se tratar de associação para tráfico internacional de entorpecentes, com atuação, no caso, no Brasil e na Alemanha, mas, também, por se imputar ao extraditando a incusão em território alemão para o mesmo fim. Hipótese, ademais, em que não há processo criminal nem mesmo inquérito policial, instaurado no Brasil, sobre os mesmos fatos. Precedentes do STF. 
extradição requerida ao Brasil quando o extraditando houver de responder, no Estado requerente, perante tribunal ou juízo de exceção. Essa vedação para a análise da Suprema Corte é absoluta. $A$ apreciação| nesta hipótese não é sobre um crime, nele analisado caráter político ou comum. Trata-se de submeter a juízo a autoridade judiciária que um Estado soberano investiu no poder decisório, havendo-a, conforme o caso, por irregular ou por excepcional..$^{29}$

O posicionamento do Supremo é pela não extradição nestes casos. Todavia, contrariando a regra, foi concedida a extraditio na histórica decisão de $n^{\circ} 347$ de 1977 . Pedido de extradição da Itália, apontada e reconhecida pelo Procurador da República brasileiro, como tribunal de exceção. O Procurador da República na época era o eminente Francisco Rezek que assim se manifestou sobre o caso: $O$ princípio de efeito útil, elementar em hermenêutica jurídica, prescreve, desde logo, a idéia simplista de que juizo de exceção seja aquele precipuamente destinado ao processo e julgamento de crimes politicos. Quando assim fosse, ter-seia o legislador contentado com a relação do inciso VII, capaz de cobrir o seu duplo propósito. Se o rol condicionante se estende até um inciso VIII, versando de modo autônomo a excepcionalidade do juizo, é porque esta se presume possivel também em presença de delitos comuns. Aquele mesmo principio hermenêutico, agora associado ao da compreensão sistemática da lei, manda que se condene, na matéria em exame, uma restrição excessiva do conceito de tribunal excepcional. ${ }^{30}$

A posição atual adotada pelo Supremo é pela denegação do pedido extradicional havendo a posterior submissão do alienígena a juízo de exceção. ${ }^{31}$

29 Op.cit. p. 7. REZEK, José Francisco. in Direito Internacional Público. São Paulo: Saraiva, 1998, p. 205.

30 Revista de Informação Legislativa, a.21, n. 83 jul/set., 1984, p. 100-101.

31 Extradição n ${ }^{\circ} 417$ - República Argentina. Relator: Min. Oscar Correia. Extradição - Lei de anistia do pais requerente inaplicável à hipótese, não atingindo o extraditando. Prevalência dos crimes comuns sobre o político, aplicando-se os $\S \S 1^{\circ} \mathrm{a} 3^{\circ}$ do art. $77 \mathrm{da} \mathrm{Lei} n^{\circ} 6.815 / 80$, de exclusiva apreciação da Corte: fatos que caracterizam, em princípio, terrorismo, sabotagem, seqüestro de pessoas, propaganda de guerra e processos violentos de subversão da ordem. Alegação improcedente de submissão a juízos de exceção. Exclusão dos delitos relativos a: liderança de movimento político, porte de armas e explosivos, e uso de documentos falsos; bem como ressalvado que não poderão ser impostas ao extraditando penas superiores a trinta anos de prisão, o máximo, em relação a cada crime. Extradição deferida com as ressalvas enunciadas. 


\section{Do caráter penal do delito}

A terceira condição para a concessão da extradição pelo Brasil concerne à natureza do delito, que deve ser penal comum, não se admitindo os crimes de cunho político, de opinião, ${ }^{32}$ de imprensa, religiosos ou militares. $\mathrm{O}$ delito político é conforme Luiz Alberto Araújo e Regis Prado, todo ato lesivo à ordem político-jurídica interna ou externa do Estado. Objetiva ele predominantemente destruir, modificar ou subverter a ordem política institucionalizada unidade orgânica do Estado.

A Lei $n^{\circ} 6.815 / 80$, no art. 77 , VII prevê que não se concederá a extradição quando o fato constituir crime político.

Luis Jimenez de Asua divide o delito político em três espécies: a) delitos puros são os que se dirigem contra a forma e a organização política de um Estado; b) delitos complexos são os que lesionam ao mesmo tempo a ordem política e o direito comum, como o homicídio de um chefe de Estado ou de governo; c) delitos conexos à delinqüência política, no sentido de meio a fim, ou conexos para o objetivo de insurreição política, realizados pelos mesmos motivos políticos. Por outro lado, alguns autores falam em delitos puramente políticos e delitos relativos, ou mistos. Estes últimos são crimes comuns dominados por motivação política. ${ }^{33}$
Antes do século XIX os criminosos políticos não encontravam refúgio, além fronteiras. A mudança dessa situação foi uma conquista dos juristas daquele século, acolhida posteriormente pelo Instituto de Direito Internacional, na sessão de Oxford, de 1980, e depois pelo Código de Bustamante.

Gilda Russomano, citada por Luis Ivani Araújo, ressalta que se vem colocar certas infrações em que a finalidade política ou o motivo político se encontram mesclados à prática de atos violadores do direito comum. Assim, segue Amorim Araújo, manifestando que os delitos conexos, em que se verifica a existência simultânea de duas infrações: uma política e outra comum, unidas por um laço de conexidade, e os complexos, isto é, os que embora ferindo, a um só tempo, a ordem política e o direito comum constituem ato único e inseparável em seus elementos. ${ }^{34}$

As legislações modernas na sua quase totalidade adotam o princípio da inextraditabilidade do criminoso político. Em 1977, o Projeto da Convenção Interamericana sobre Extradição, aprovado, pelo Comitê Jurídico Interamericano, estabeleceu que a extradição não procede: Cuando con arreglo a la calificación del Estado requerido se trate de delitos políticos, o de delitos conexos. La circunstancia

32 Conforme art. $5^{\circ}, \mathrm{LII}, \mathrm{CF} / 88$.

33 Revista de Informação Legislativa, a.19, n.76, out/dez., 1982, p. 79.

34 in Curso de Direito Internacional Público, 5.ed. Rio de Janeiro: Forense, 1987, p. 357. 
de que la víctima del hecho punible de que se trata ejerciera funciones políticas no justifica por si sola que dicho delito sea calificado como político (art. II, parágrafo $4^{\circ}$ ). A matéria é ainda hoje controvertida na doutrina por conseqüência da competência do Supremo para analisar e determinar se o delito é ou não de natureza política. ${ }^{35}$

Sobre a matéria o Supremo Tribunal Federal tem se posicionado no sentido da análise da preponderância do caráter político do delito, denegando o envio quando se tratar de crimes complexos. ${ }^{36}$

\section{Da nacionalidade do extraditando}

Como já foi analisado anteriormente no capítulo sobre o fundamento nacional para a extradição baseada na Constituição Federal, é vedada, conforme art. 77, I do Estatuto do Estrangeiro a extradição quando se tratar de brasileiro, salvo se a aquisição dessa nacionalidade verificar-se após o fato que motivar o pedido.

Assim, o brasileiro nato nunca será extraditado; a exceção para o envio ocorre nos casos de brasileiro naturalizado, pendente análise da época da naturalização (que deve ter ocorrido após o fato motivador do pedido de extradição) ou independentemente de data da naturalização, em função da espécie de crime cometido - tráfico ilícito de entorpecentes e drogas afins. A interpretação do STF sobre a matéria é vista na Extradição no 541 (RTJ 149/ 428), cujo relator foi o Min. Sepúlveda Pertense, valendo ressaltar trecho específico da ementa:

Ao princípio geral de inextraditabilidade do brasileiro, incluido o naturalizado, a Constituição admitiu, no art. $5^{\circ}, L I$, duas exceções: a primeira, de eficácia plena e aplicabilidade imediata, se a naturalização é posterior ao crime comum pelo qual procurado; a segunda, no caso de naturalização anterior ao fato, se cuida de tráfico de entorpecentes: ai, porém, admitida, não como a de qualquer estrangeiro, mas sim na forma da lei e por comprovado envolvimento no crime: a essas exigências de caráter

\footnotetext{
35 Ver art. 77, § 2 Estatuto do Estrangeiro. Assim foi no caso da Extradição $\mathrm{n}^{\circ} 417$, de Eduardo Firminich à Argentina, em 1984 (RTJ 111/13).

36 Extradição no 524 - Paraguai. Rel. Min. Celso de Mello. Extradição passiva - natureza do processo extradicional - limitação jurídica dos poderes do STF - inextraditabilidade por delitos políticos - compromisso constitucional do Estado brasileiro - asilo político extradição política disfarça - inocorrência - deficiência na formulação do pedido de extraição - inobservância do Estatuto Estrangeiro e do tratado de extradição Brasil/Paraguai incerteza quanto à adequada descrição dos fatos delituosos - ônus processual a cargo do estado requerente-descumprimento - indeferimento do pedido. (DJU 08.03.1991).
} 
excepcional não basta a concorrência dos requisitos formais de toda extradição, quais sejam, a dúplice incriminação do fato imputado e o juizo estrangeiro sobre a seriedade da suspeita.

\section{Da dupla tipicidade}

Além dos requisitos já estudados prevê o artigo 77, II, conforme o critério de exclusão, que não se concederá a extradição se o fato que motivar o pedido não for considerado crime no Brasil ou no Estado requerente.

É uma garantia essencial ao direito de liberdade que o fato ensejador da extradição deva ser tipificado como crime por ambas as leis em confronto, para que seja procedida a extradição pelo Brasil. Como informa o insigne professor Francisco Rezek pouco importam as variações terminológicas, e irreleva, até mesmo, a eventualidade de que o Estado requerente o classifique na categoria intermediária dos delitos. ${ }^{37}$

Neste sentido é manifestada a interpretação do Supremo Tribunal Federal: Revela-se essencial, para a exata aferição do respeito ao postulado da dupla incriminação, que os fatos atribuídos ao extraditando - não obstante a incoincidência de sua designação formal - revistam-se de tipicidade penal e sejam igualmente puníveis tanto pelo ordenamento jurídico doméstico quanto pelo sistema de direito positivo do Estado requerente. Precedente: RTJ 133/1075. ${ }^{38}$

O requisito da dupla incriminação ou tipicidade também conhecido como princípio da identidade admite a entrega de extraditando que esteja respondendo a processo ou já condenado por contravenção penal no Brasil (art. 90 do Estatuto do Estrangeiro). Todavia será negado pedido de Estado estrangeiro, se apesar de ser crime no ordena-mento jurídico estrangeiro, for tipificado como contravenção no Brasil. ${ }^{39}$

A legislação pátria analisa não só a tipicidade da conduta como também os demais elementos do crime como a culpabilidade e punibilidade. Neste caso, o STF denegaria, e.g., a extradição de menor de 18 anos reclamado por homicídio pela Argentina ou pelos Estados Unidos. Porque os três sistemas penais tipificam o ato de matar alguém. Todavia pelas provas que instruem o pedido perceberiam os julgadores que o ato concreto carece, perante nossa legislação penal interna,

37 Op.cit. p. 7, in Direito Internacional Público - Curso Elementar, p. 203.

38 Informativo do STF - Brasília, n. 22, 4 a 8 de março de 1996.

39 Neste sentido: extradição no 753 - Estados Unidos. Rel. Moreia Alves, Diário da Justiça-seção I, 26 nov. de 1999, p. 83. 
do requisito da punibilidade, sendo denegado o envio. ${ }^{40}$

A interpretação do Supremo é cristalina em indeferir extradição passiva quando o fato motivador do pedido não configurar crime em ambos os Estados, no requerente e no Brasil. $^{41}$

\section{Da gravidade do delito}

A extradição, como instituto baseado na cooperação internacional para o fim de reprimir a impunibilidade com a devolução do delinqüente a jurisdição de direito para processá-lo e julgá-lo só se justifica por crime de certa gravidade e não se aplica a simples contravenções. É o que espelha o artigo 77 em seu inciso IV: Não se concederá a extradição quando: a lei brasileira impuser ao crime a pena de prisão igual ou inferior a um ano.

Em que pese a simples leitura desse dispositivo depreende-se que são excluídos das hipóteses de extradição os delitos a que a lei brasileira impuser as penas de multa ou restritivas de direitos por entender que estas só se aplicam a crimes com menor gravidade e a exclusão compulsória de um indivíduo do país somente se procederá por motivos graves, segundo os princípios do direito pátrio, acata a determinação da sessão de 1880, em Oxford, do Instituto de Direito Internacional, ao afirmar que "a extradição, sendo sempre medida grave, só se deve aplicar a infrações de certa importância".

Explicita ainda o Estatuto do Estrangeiro que não basta tratar-se de crime com pena privativa de liberdade; esta pena cominada - abstrata, deverá ser de no mínimo um ano, o que exclui do rol dos crimes sujeitos a extradição delitos como: lesão corporal, rixa, calúnia, constrangimento ilegal, maus tratos... Esta determinação está na maioria dos tratados firmados pelo Brasil sobre o tema: Assim, com a mesma redação supra citada e constante no artigo II, temos tratado de extradição entre o Brasil e Venezuela (1940); Colômbia (1940); Bélgica (1957); Estados Unidos (1965) este no artigo III e Argentina (1968) no artigo II, exigindo pena de dois anos ou mais de prisão, entre outros tratados.

40 A lei argentina também exige a dupla incriminação, tendo-a como princípio da identidade de norma: No procede extradición si el hecho inculpado al individuo no constituye, a la vez, delito, según la legislación de ambos estados, requirente y requerido.

41 Extradição n ${ }^{\circ} 687$ - Reino da Espanha. Rel. Min. Maurício Correa. Extradição - Tratado entre a República Federativa do Brasil e o Reino da Espanha - Crime de Peculato. Fundandose o pedido em Tratado de Extradição firmado entre a República Federativa do Brasil e o Reino da Espanha, em 02.02.1988 e promulgado pelo Decreto no 99.340 , de 22.06.1990, está assim atendido o requisito autorizativo da medida, previsto no art. 76 da Lei 6.815/80. $\mathrm{O}$ delito de peculato, definido na legislação penal espanhola, configura crime previsto no Brasil (art. 312 do CP) (DJU 21.02.1997). 
A Suprema Corte tem se manifestado no sentido de acatar essa determinação do Estatuto do Estrangeiro. ${ }^{42}$

\section{Do princípio do non bis in idem}

A expressão latina non bis in idem, significa não duas vezes pela mesma coisa. Trata-se de axioma jurídico, em virtude do qual ninguém pode responder, pela segunda vez, sobre o mesmo fato, já julgado, ou ser duplamente punido pelo mesmo delito. ${ }^{43}$

Neste sentido é prevista vedação da extradição-art. $77, \mathrm{~V}$ da Lei $\mathrm{n}^{\circ} 6.815 / 80$ - quando o extraditando estiver a responder a processo ou já houver sido condenado ou absolvido no Brasil pelo mesmo fato em que fundar o pedido. Sendo o Brasil Estado requerido em processo de extradição não será outorgado o pedido se o ilícito penal a motivar a extradição já estiver sendo processado ou já tenha sido julgado pelo poder judiciário no Brasil, pois estar-seia infringindo um preceito fundamental do direito penal e dos direitos humanos caso fosse imposto a um indivíduo responder judicialmente mais de uma vez pelo mesmo fato.

Este princípio aplicado pela legislação pátria está presente em vários tratados de extradição feitos pelo Brasil, dentre eles com a Venezuela
(1940), Colômbia (1940), Bélgica (1957), Argentina (1968) em todos no inciso III, acrescentando a denegação da extradição também nos casos de anistia ou indulto em qualquer dos Estados, requerente ou requerido e com os Estados Unidos (1965) no artigo $5^{\circ}$, II, especificando que não será concedida a extradição em qualquer das seguintes circunstâncias - II: quando o indivíduo cuja entrega já tenha sido julgado ou, ao tempo do pedido, esteja sendo processado no Estado requerido, pelo crime ou delito que ocasionou o pedido de extradição. A Comunidade Européia também segue o princípio, conforme determina a Resolução da Assembléia da República $n^{\circ}$ 22/95: Convenção entre os Estados membros das Comunidades européias sobre a Aplicação do Princípio do ne bis in idem, em seu art. $1^{\circ}$ : Quem tiver sido definitivamente julgado num Estado membro não pode, pelos mesmos fatos, ser perseguido num outro Estado membro, desde que, em caso de condenação, a sanção tenha sido cumprida, esteja efetivamente em curso de execução ou já não possa ser executada segundo as leis do Estado da condenação.

O Supremo Tribunal Federal tem se manifestado sobre a matéria com acato literal da previsão legal do Estatuto do

42 Extradição no 308 - Estados Unidos. Rel. Min. Eloy da Rocha. Extradição. Solicitação que satisfaz aos requisitos legais. Condenação por crime a que se aplica, na lei brasileira, pena de prisão superior a um ano. Extradição concedida (1971).

43 NUNES, Pedro. in Dicionário de Tecnologia Jurídica. 12. ed. Rio de Janeiro: Freitas Bastos, 1994, p. 605. 
Estrangeiro, para vedar a possibilidade de dupla responsabilização do sujeito pelo mesmo fato delituoso. ${ }^{44}$

\section{Da prescrição do crime}

A prescrição como forma da perda do ius puniendi do Estado pelo decurso do tempo fixado em lei é presente também no processo extradicional dentre os pressupostos relativos ao fato imputado ao extraditando, prevista no art. 77, VI, da Lei $n^{\circ}$ 6.815/80: Não se concederá a extradição quando extinta a punibilidade pela prescrição segundo a lei brasileira ou a do Estado requerente.

A legislação Argentina também prevê o requisito da imprescritibilidade para a concessão da extradição: $L a$ conducta que configura el delito objeto de extradición, como es obvio, no debe estar prescripta según los cânones legales del Estado requirente, cuyo extremo es consagrado en forma expressa en el art.
19, num. 4, conforme Bermudez, in La Extradición, p. 206.

É cristalino o dispositivo legal ao permitir a concessão do pedido diante da inocorrência de prescrição da pretensão punitiva ou executória, seja pelas leis brasileiras, seja pela lei do Estado estrangeiro requerente. Importante ressaltar que a prescrição deve ser perquirida, separadamente, primeiro quanto à legislação pátria, e após, quanto à legislação do Estado requerente.

Verificada a incidência da prescrição e extinta a punibilidade do infrator, a Suprema Corte brasileira tem se posicionado da seguinte maneira: ou indefere o pedido de extradição ou julgao prejudicado. Neste sentido tem se manifestado o Supremo Tribunal Federal. ${ }^{45}$

\section{CONCLUSÃO}

As fronteiras do mundo estão desaparecendo. Os Estados estão cada

44 Extradição no 664-9 - Espanha. Rel. Maurício Correa. Extradição. Tráfico de Entorpecentes. Condenação no Brasil e na Espanha por crimes autônomos. Tratado de Extradição Brasil - Espanha de 02.02.1988, promulgado pelo Decreto n 99.340, de 1990. Aplicação. Prescrição extraditando com cônjuge e filho no Brasil. 3. Não há óbice para o deferimento da extradição se a condenação sofrida no Brasil tem por base fato diverso daquele que se funda o pedido do Estado Requerente. (art. 77, V, da Lei 6.815/80).

45 Extradição n ${ }^{\circ}$ 560. Reino da Bélgica. Rel. Min. Moreira Alves. Extradição, Prisão e Prescrição. Julgando pedido de extradição formulado pelo governo da Bélgica o Tribunal afastou a alegação de prescrição da pretensão executória deduzida com fundamento na legislação belga, por entender que a prisão do extraditando, mesmo tendo sido efetuada no Brasil para fins de extradição, é causa interruptiva da prescrição, o art. 96 do Código Penal da Bélgica (o trânsito em julgado da sentença penal condenatória - termo inicial do prazo - ocorrera em 15.12.90 e o réu foi preso no Brasil em 22.03.95) (27.03.96). 
vez mais próximos em conseqüência do progresso tecnológico, dos meios de comunicação até poucas décadas passadas inimagináveis como a internet e com os interesses direcionados para o desenvolvimento comum para sobrevivência de todos os povos através das comunidades de Estados, como a Comunidade Européia e o Mercosul.

Neste contexto de globalização aumentam além das vantagens advindas da integração, os malefícios que a mesma proporciona, como a facilidade de fuga além fronteiras de delinqüentes a fim de furtarem-se de responder por seus atos a quem de direito.

Destarte a extradição, como mecanismo de cooperação internacional para reprimir tais tentativas furtivas, é essencial em sua finalidade, nos tempos em que vivemos. Trata-se de um ato de soberania efetivado com a entrega de um indivíduo a um país que o requeira para que nele seja processado ou cumpra pena por delito comum que the foi imputado.

No presente estudo de cunho bibliográfico e jurisprudencial foram tecidas considerações gerais sobre a matéria bem como abordado o seu fundamento jurídico, que no âmbito do direito internacional deve ser baseado em tratado internacional bi ou multilateral, com efeito vinculatório para os contratantes, prevendo as condições gerais e as específicas para o procedimento e apresentando estes tratados o escopo de proteger os Estados fracos das pressões, muitas vezes injusti- ficadas, dos Estados fortes e constituir medida preventiva do delito pela advertência que fazem aos criminosos eventuais. Viu-se que na falta de tratados pode-se substanciar a extraditio em compromisso de reciprocidade entre o Estado requerente e o requerido, constituindo em promessa de que ocorrendo crime análogo no país requerido o país requerente se comprometa a conceder a extradição solicitada. No que concerne aos fundamentos nacionais do pedido foram analisados os dispositivos constitucionais a respeito que determinam que o brasileiro nato nunca será extraditado e quanto ao naturalizado a Constituição Federal prevê sua concessão pendente análise dos requisitos do tempo de naturalização e da espécie de delito praticado. Todavia além das determinações constitucionais regem a matéria leis esparsas que foram ao longo do tempo aprimorando-se até o atual Estatuto do Estrangeiro - Lei ${ }^{\circ} 6.815 /$ 80 e a Lei Federal $n^{\circ} 6.964 / 81$.

Numa segunda parte do estudo foi examinada a competência para o processo e julgamento da extradição que é do Supremo Tribunal Federal, no Brasil, em que pese ser um processo de natureza mista: administrativo, com pedido e entrega feitos de governo a governo e, judiciário, com o exame e autorização pela Suprema Corte do poder judiciário.

Outrossim, foi vista a interpretação e aplicação dada pelo Supremo Tribunal Federal quanto aos requisitos formais e 
materiais exigidos para a extradição constantes da Lei $n^{\circ} 6.815 / 80$, que obedecem a critério de exclusão. Nestes termos não se concederá a extradição além da já mencionada nacionalidade brasileira, quando não houver dupla tipicidade do fato motivador do pedido, quando for o caso de competência brasileira para julgar o crime. Só haverá extradição por crime de certa gravidade, pois esta constitui-se em ato drástico de retirada compulsória de indivíduo do país e não se presta para delitos menores, como as contravenções; o Brasil segue o princípio do non bis in idem - o extraditando não responderá duas vezes em Estado diverso e no Brasil pelo mesmo fato; prescrito o crime motivador do pedido em algum dos Estados, não será a extradição concedida devido à extinção da punibilidade. Outrossim, crimes políticos e de opinião, religiosos e militares estão fora do rol dos passíveis de extradição, e vedação em caso de responder o extraditando a juízo ou tribunal de exceção.

Assim foi cumprido o propósito deste estudo de analisar alguns aspectos deste importante instituto que é de direito internacional, mas se encontra regulado no direito interno de todos os países. 
